\title{
PENDAMPINGAN PENERAPAN DIGITAL MARKETING SEBAGAI STRATEGI MARKETING PADA UMKM BAKPAO IJO LUMER
}

\author{
Dina Mahesti, Andhita Risko Faristiana \\ Fakultas Tarbiyah dan Ilmu Keguruan \\ Institut Agama Islam Negeri Ponorogo, Jawa Timur \\ dinamahesti8@gmail.com, andhitarisko@iainponorogo.ac.id
}

\begin{abstract}
The development of technology today has been increasingly advanced and developed, especially social media that greatly impact and affect people's lives. The development of technology also has an impact on marketing, especially in the process of buying and selling, Digital Marketing is one of the marketing strategies that can reach the wider community from the top to the bottom. Research in this training uses the ABCD method or this training using the ABCD approach that is Asset Based Community Development, which prioritizes the utilization of assets and potential that exist around and owned by the community. Marketing planning in this study aims to develop MSMEs Bakpao Ijo Lumer in Milangasri District Panekan which due to pandemic vovid-19 began to decrease sales, the problems faced by bakpao ijo sellers one of them is in marketing or marketing, With this research bakpao ijo sellers can better know the benefits of technology, especially digital marketing to advertise or sell their bakpao ijo lumer food products, so that with this digital marketing sales turnover and public interest to buy bakpao ijo lumer increases, besides that sellers also get a lot of useful knowledge about digital marketing technology to be able to compete with the market and compete with other bakpao ijo products or other food products that are similar or different.
\end{abstract}

Keywords: Digital Marketing, Strategy, Marketing, ABCD

\begin{abstract}
Abstrak
Perkembangan teknologi saat ini sudah semakin maju dan berkembang, terutama media sosial yang sangat berdampak dan mempengaruhi kehidupan masyarakat. Perkembangan teknologi juga berdampak pada pemasaran terutama dalam proses jual beli, Digital Marketing merupakan salah satu strategi pemasaran yang dapat menjangkau masyarakat luas mulai dari kalangan atas sampai bawah. Penelitian dalam pelatihan ini menggunakan metode ABCD atau Pelatihan ini menggunakan pendekatan ABCD yaitu Asset Based Community Development, yang mengutamakan pemanfaatan aset dan potensi yang ada di sekitar dan dimiliki oleh komunitas masyarakat. Perencanaan marketing dalam penelitian ini bertujuan untuk mengembangkan UMKM Bakpao Ijo Lumer didesa Milangasri Kecamatan Panekan yang akibat pandemic vovid-19 mulai menurun penjualannya, permasalahan yang dihadapi penjual bakpao ijo salah satunya adalah dalam pemasaran atau marketing, dengan penelitian ini penjual bakpao ijo bisa lebih mengetahui manfaat dari teknologi terutama digital marketing untuk mengiklankan atau menjual produk makanan bakpao ijo lumer miliknya, sehingga dengan digital marketing ini omset penjualan dan minat masyarakat untuk membeli bakpao ijo lumer meningkat, selain itu penjual juga mendapat banyak sekali ilmu yang bermanfaat mengenai teknologi digital marketing untuk bisa bersaing dengan pasar dan bersaing dengan produk bakpao ijo lain ataupun produk makanan lain yang serupa maupun berbeda.
\end{abstract}

Kata Kunci: Digital Marketing, Strategi, Marketing, ABCD

Sarwahita : Jurnal Pengabdian Kepada Masyarakat Vol. 18 No. 2 Tahun 2021 | 157 


\section{PENDAHULUAN}

Perkembangan teknologi saat ini sudah semakin maju dan berkembang, terutama media sosial yang sangat berdampak dan mempengaruhi kehidupan masyarakat. Perkembangan teknologi juga berdampak pada pemasaran terutama dalam proses jual beli. Digital Marketing dikenal pertama kali pada awal tahun 1990-an dan mulai menjadi strategi utama yang banyak diterapkan dalam dunia bisnis pada tahun 2014. Digital Marketing merupakan perwujudan dari penerapan, penggunaan atau pemanfaatan dari teknlogi dalam proses pemasaran, yang terjadi dengan beberapa tahapan sebagai berikut(Ryan, 2014:4): a. Teknologi baru muncul dan awal sekali digunakan, b. Teknologi mulai diperkenalkan dan diutamakan dalam dunia pemasaran, c. Para pemasar yang inovatif melakukan ekplorasi dan terobosan ntuk dapat meningkatkan fungsi atau kegunaan tknologi untuk mencapai target dari pemasaran, d. Teknologi menjadi strategi utama yang digunakan untuk kegiatan pemasaran. Namun penerapan teknologi digital marketingjuga harus disesuaikan dengan bisnis atau produk yang dijual, agar nanti ketika mulai berjualan produk dengan strategi yang digunakan juga dapat sesuai, Digital Marketing merupakan salah satu cara pemasaran yang memanfaatkan teknologi dan juga dengan ketrampilan dalam menggunakan digital marketing dalam memulai bisnis atau pemasaran produk yang akan dilakukan dan manfaat dari digital marketing adalah untuk memudahkan dalam pemasaran produk yang akan dijual untuk menarik minat pembeli dengan memasang iklan produk sebagus dan semenarik mungkin.

Digital Marketing merupakan salah satu strategi pemasaran yang dapat menjangkau masyarakat luas mulai dari kalangan atas sampai bawah. Perencanaan marketing dalam penelitian ini bertujuan untuk mengembangkan UMKM Bakpao Ijo Lumer didesa Milangasri Kecamatan Panekan yang akibat pandemic vovid-19 mulai menurun penjualannya, permasalahan yang dihadapi penjual bakpao ijo salah satunya adalah dalam pemasaran atau marketing, kurangnya penjual bakapo ijo yang mengetahui mengenai perkembangan dan penggunaan teknologi terutama digital marketing membuat semakin sepinya penjualan bakpao ijo. Masih manualnya marketing yang dilakukan penjual bakpao ijo lumer membuat jangkauan mengenai pemasaran bakpao ijo sedikit dan tidak luas sehingga saat ini penjualan menurun drastis

Pandemi Covid-19 memberikan dampak besar didunia telah merubah seluruh sector, khususnya sektor ekonomi. Para pelaku usaha, khusunya Usaha Mikro Kecil Menengah (UMKM) memperoleh dampak yang sangat signifikan (Andi Armi, 2020) (Khofifah Nur Ihza, 2020). tingkat kecepatan dan cakupan penyebaran virus corona melebihi kejadian kasus lainnya yang mengakibatkan kondisi negara Indonesia menjadi tidak stabil terutama di bidang perekonomian. Upaya sudah dilakukan pemerintah dalam mengatasi pandemi covid-19 yang terjadi, upaya penanganan 
yang dilakukan pemerintah menyebabkan perubahan sosial yang ada di masyarakat, perubahan di berbagai bidang kehidupan masyarakat dan juga perilaku masyarakat. Pengaruh dari pandemi covid-19 ini cukup besar dan sangat berdampak dalam berbagai bidang kehidupan masyarakat.Pandemi mengakibatkan kerugian bagi Indonesia, banyak sekali orang terpapar atau terkena wabah tersebut bahkan juga ada banyak sekali orang yang meninggal akibat wabah tersebut, selain itu wabah virus corona juga mengakibatkan ketidakstabilan dibidang perekonomian di Indonesia yang menyebabkan banyak terjadinya krisis ekonomi dan krisis pangan, selain itu masyarakat juga kesulitan dalam memenuhi kebutuhan hidupnya akibat pandemi Covid-19 yang hingga saat ini masih terus berlangsung. Menurut Mulyono (2021), akibat wabah Covid-19 pasar dan tempat dagang yang mayoritas menyebabkan kerumunan ditutup dan pemberlakuan PSBB, PBB pertama kali dicetuskan oleh ketua gugus tugas percepatan penanganan covid-19 yaitu Doni Monardo dalam konferensi pers pada hari selasa 12 Mei 2020. Pemberlakuan PSBB ini membuat salah satu masyarakat daerah PenekanMagetan yang menjadi pembuat sekaligus penjual Bakpao Ijo tidak bisa berjualan, hal ini mengakibatkan penjual bakpaoijotidak mempunyai penghasilan tetap dan sulit untuk memenuhi kJebutuhan hidupnya karena sepinya pembeli dan berkurangnya minat pembeli dan ditambah lagi dengan banyaknya penjual bakpao ijo yang lain yang memiliki rasa, bentuk, dan varian yang berbeda.

Sulitnya berjualan dimasa pandemi seperti ini membuat penjual bakpao ijo sebagian besar gulung tikar, namun tidak dengan penjual bakpao ijo di desa Milangasri kecamatan Panekan ini, beliau masih tetap semangat menjual bakpao ijo dengan berjualan keliling dan membuka pesanan baik dalam jumlah kecil maupun besar. Saat pandemi seperti ini kita harus berusaha dan sebisa mungkin memanfaatkan segala sesuatunya sebaik mungkin terutama mengenai pemanfaatan media teknologi yang ada misalnya seperti Instagram, Facebook, WhatsApp dan lain sebagainya, salah satu media yang efektif untuk pemasaran online adalah Instagram yang memiliki keunggulan penggunaanyang mudah karena hanya membagi gambar dan kontak dari penjual (Khrisna Hadiwinata dkk, 2020) (Hafidh Irfansyah dkk,2020). Karena saat ini yang menjadi pusat perhatian masyarakat lebih kepada teknologi, dengan memanfaatkan teknologi yang ada diharapkan dapat meningkatkan pendapatan penjualan Bakpao ijo karena dimasa pandemic seperti ini masyarakat lebih mngurangi aktifitas diluar rumah dan sebagian besar masyarakat dalam menghilangkan kejenuhan saat dirumah adalah dengan bermain media sosial dan memanfaatkan teknologi yang ada, selain untuk menghilangkan kejenuhan media sosial juga bisa digunakan untuk berjualan dan mengembangkan bisnis secara online.

Penelitian ini dilakukan guna mengetahui bagaimana proses pelatihan marketing bakpao ijo milik bapak 
Mukhlisin yang terletak didesa Milangasri kecamatan Panekan ini dan bagaimana proses pemasarannya, apakah sudah berjalan dengan baik dan terlaksana sesuai dengan keinginan untuk dipasarkan di masyarakat terutama masyarakat yang dari dulu sudah menjadi langganan bakpao ijo maupun masyarakat lain yang baru mengetahui bakpao ijo lumer milik bapak Mukhlisin. Penlitian ini bertujuan untuk memberikan pelatihan penerapan digital marketing sebagai strategi marketing pada UMKM bakpao ijo lumer sehingga dapat menghasilkan marketing yang dapat menjangkau masyarakat luas, meningkatkan jumlah konsumen dan menarik minat pembeli agar membeli bakpao ijo lumer. Dan penelitian ini juga bertujuan meningkatkan pendapatan penjual bakpao ijo dimasa covid-19 saat ini serta bagaimana atau usaha apa saja yang dilakukan penjual bakpao ijo dalam menarik minat masyarakat agar membeli bakpao ijo dan strategi apa saja yang dilakukan pedagang bakpao ijo serta sudah sejauh apa proses marketing atau pemasaran dengan pemanfaatan digital marketing dengan hasil yang didapatkan terutama saat pandemi covid-19 dan dengan adanya penerapan kebijakan PPKM yang sampai saat ini masih berlaku dan kemungkinan akan terus diperpanjang.

\section{METODE PELAKSANAAN}

Asset Based Community Development (ABCD)

Pelatihan ini menggunakan pendekatan ABCD yaitu Asset Based
Community Development, yang mengutamakan pemanfaatan aset dan potensi yang ada di sekitar dan dimiliki oleh komunitas masyarakat. Komunitas masyarakat dalam hal ini yaitu Penjual Bakpao Ijo lumer penjual tersebut adalah Bapak Mukhlisin yang bertempat tinggal di KPR Taman Asri yang terletak di Desa Milangasri Kecamatan Panekan, penjual bakpao ijo merupakan salah satu aset atau potensi di Desa Milangasri yang perlu dikembangkan dengan pelatihan-pelatihan dengan memanfaatkan teknologi yang semakin canggih yaitu dengan penerapan digital marketing.

Berdasarkan observasi awal tersebut peneliti akhirnya memutuskan untuk mengadakan pelatihan mengenai penerapan digital marketing untuk melancarkan strategi marketing dalam UMKM bakpao ijo lumer milik bapak mukhlisin agar dapat dipasarkan secara luas di masyarakat dan untuk mencapai tujuan pelatihan penerapan digital marketing sebagai strategi marketing peneliti berusaha semasimal mungkin agar kegiatan ini dapat berjalan dengan baik dan bakpao ijo lumer milik bapak Mukhlisin dapat dikenal oleh masyarakat dan dapat menigkat penjualnnya. Dalam metode ABCD memiliki 5 langkah kunci untuk melakukan proses riset pendampingan.

Teknik-Teknik Pendampingan

Metode dan alat untuk memobilisasi aset pemberdayaan masyarakat melalui Asset Based Community Development $(\mathrm{ABCD})$, antara lain: 
a. Penemuan Apresiatif (Appreciative Inquiry)

Appreciative Inquiry (AI) adalah cara yang positif untuk melakukan perubahan organisasi berdasarkan asumsi yang sederhana yaitu bahwa setiap organisasi memiliki sesuatu yang dapat bekerja dengan baik, sesuatu yang menjadikan organisasi hidup, efektif dan berhasil, serta menghubungkan organisasi tersebut dengan komunitas dan stakeholder-nya dengan cara yang sehat. AI tidak menganalisis Akar masalah dan solusi Tetapi lebih konsen pada Bagaimana memperbanyak hal-hal positif dalam organisasi. Proses. AI ini diwujudkan dengan adanya Forum Group Discussion (FGD) yang dilakukan pada jenjangnya masing-masing.

Appreciative Inquiry (AI) secara teknis mekanisme pemberdayaan terdiri dari empat tahap yaitu: Discovery, Dream, Design dan Destiny atau sering disebut model atau siklus 4-D.

1. Discovery

Tahap Discovery adalah eksplorasi mendalam tentang halhal positif, hal-hal terbaik yang pernah di capai, dan pengalaman sukses dimasa lalu. Proses ini dilakukan melalui wawancara apresiatif.

\section{Dream}

Pada tahap Dream, setiap orang mengeksplorasikan harapan dan impian mereka baik untuk diri sendiri maupun untuk organisasi. Orang-orang mulai memikirkan hal besar dan berpikir out of the box serta membayangkan hasilhasil yang ingin dicapai.

3. Design

Pada tahap Design ini, orang mulai merumuskan strategi, proses dan sistem, membuat keputusan dan mengembangkan kolaborasi yang mendukung terwujudnya perubahan yang diharapkan.

4. Destiny

Tahap Destiny adalah tahap dimana setiap orang dalam organisasi mengimplementasikan berbagai hal yang sudah dirumuskan pada tahap Design. Tahap-tahap ini berlangsung ketika organisasi kontinyu menjalankan perubahan, memantau perkembangannya, dan mengembangkan dialog, pembelajaran dan inovasi-inovasi baru.

b. Pemetaan Komunitas (Community Mapping)

Pendekatan atau cara untuk memperluas akses ke pengetahuan lokal. Community Map merupakan visualisasi pengetahuan dan persepsi berbasis masyarakat mendorong pertukaran informasi dan menyetarakan bagi semua masyarakat untuk berpartisipasi dalam proses yang mempengaruhi lingkungan dan hidup mereka.

\section{c. Penelusuran Wilayah (Transet)}

Transet adalah garis imajiner sepanjang suatu area tertentu untuk menangkap keragaman sebanyak 
mungkin. Dengan berjalan sepanjang garis itu dan mendokumentasikan hasil pengamatan, penilaian terhadap berbagai aspek dan peluang dapat dilakukan. Penelusuran wilayah dilakukan bebarengan dengan pemetaan komunitas (community Mapping).

\section{d. Pemetaan Asosiasi dan Institusi} Asosiasi merupakan proses interaksi yang mendasari terbentuknya lembaga-lembaga sosial yang terbentuk karena memenuhi faktor-faktor sebagai berikut: (1) Kesadaran akan kondisi yang sama, (2) Adanya relasi sosial, dan (3) Orientasi pada tujuan yang telah ditentukan.

e. Pemetaan Aset Individu (Individual Inventory Skill)

Metode atau alat yang dapat digunakan untuk melakukan pemetaan individual aset antara lain kuisioner, interview dan focusgroupdiscussion. Manfaat dari pemetaan individual aset antara lain: (a) Membantu membangun landasan untuk member-dayakan masyarakat dan memiliki solidaritas yang tinggi dalam masyarakat. (b) Membantu Membangun hubungan yang baik dengan masyarakat. (c) Membantu masyarakat mengidentifikasi keterampilan dan bakat mereka sendiri.

\section{f. Sirkulasi Keuangan (Leacky Bucket)}

Perputaran ekonomi yang berupa kas, barang dan jasa merupakan hal yang tidak terpisahkan dari komunitas dalam kehidupan mereka sehari-hari. Seberapa jauh tingkat dinaminitas dalam pengembangan ekonomi lokal mereka dapat dilihat, seberapa banyak kekuatan ekonomi yang masuk dan keluar. Untuk mengenali, mengembangkan dan memobilisasi aset-aset tersebut dalam ekonomi komunitas atau warga lokal diperlukan sebuah analisa dan pemahaman yang cermat. Salah satu pendekatan yang digunakan dalam pedekatan ABCD (Asset Based Community Development) adalah melalui Leacky Bucket.

\section{g. Skala Prioritas (Low Banging Fruit)}

Setelah masyarakat mengetahui potensi, kekuatan dan peluang yang mereka memiliki dengan melalui menemukan informasi dengan santun, pemetaam aset, penelusuran wilayah, pemetaan kelompok atau institusi dan mereka sudah membangun mimpi yang indah maka langkah berikutnya, adalah bagaimana mereka bisa melakukan semua mimpi-mimpi diatas, karena keterbatasan ruang dan waktu maka tidak mungkin semua mimpi mereka diwujudkan.

\section{HASIL DAN PEMBAHASAN}

\section{Pelaksanaan Pengabdian}

Langkah awal yang dilakukan peneliti adalah melakukan observasi awal di Rumah Bapak Mukhlisin tepatnya di KPR Taman Asri Desa Milangasri Kecamatan Panekan Kabupaten Magetan, dengan melihat secara nyata kondisi atau keadaan UMKM Bakpao Ijo milik Bapak Mukhlisin. Selain itu peniliti juga mndatangi kantor desa setempat guna meminta izin untuk melasksanakan kegiatan observasi di desa Milangasri dengan menyerahkan surat izin dari 
kampus yang menyelenggarakan kegiatan KPM. Saat peneliti mendatangi kantor kepala desa Milangasri beliau meminta agar kegiatan yang peneliti lakukan dapat memberikan manfaat dan dapat menambah wawasan masyarakat desa Milangasri tanpa terkecuali baik yang akan diobservasi maupun masyarakat lain yang bisa diberikan sosialisasi mengenai kegiatan yang akan dilakukan sehingga masyarakat juga dapat membantu peneliti dalam mensukseskan dan melancarkan kegiatan observasi yang dilakukan didesa Milangasri. Dari data yang diperoleh dan dengan melalui pertimbangan maka peniliti memutuskan Bakpao Ijo Lumer milik bapak Mukhlisin merupakan asset utama yang merupakan UMKM yang dimiliki desa Milangasri, Peniliti memutuskan adanya pelatihan mengenai penerapan pemanfaatan teknologi khususnya digital marketing dikarenakan omset penjualan yang terus menurun maka penjual bakpao ijo harus pintar mmanfaatkan dan mengelola teknologi sebaik mungkin terutama digital marketing yang jika dimanfaatkan dengan maksimal bisa menambah omset penjualan bakpao ijo lumer.

Bakpao ijo merupakan salah satu makanan dengan ciri khas warna makanan hijau muda dengan isian dan rasa coklat lumer didalamnya dengan bentuk bulat dan pipih, selain isian coklat juga terdapat beberapa isian atau varian rasa lainnya seperti : strowberry, anggur, dan kacang ijo. Bakpao ijo lumer ini merupakan salah satu UMKM yang sudah banyak penjualnya. Bapak mukhlisin merupakan salah satu penjual UMKM bakpao ijo yang mulai berjualan pada tahun 2020 silam. Beliau mulai membuka usaha dengan memproduksi bakpao ijo di tempat tinggalnya dan berlanjut hingga sekarang. Bakpao ijo milik bapak mukhlisin ini dibandrol dengan harga Rp.800,00 rupiah per pcsnya dan dan didistribusikan ke toko toko yang mulai meminta atau memesan bakpao ijo kepada bapak mukhlisin selain itu bakpao ijo ini juga dijual sendiri dirumah, bapak Mukhlisin membuka toko dengan etalase kecilkecilan yang digunakan untuk manaruh bakpao ijo buatannya. Namun karena adanya pandemi covid-19 yang sampai sekarang belum bisa diatasi membuat penjualan bakpao ijo mulai menurun ditambah dengan adanya kebijakan PPKM yang masih terus diperpanjang membuat pendapatan dan permintaan konsumen bakpao ijo terus menurun, untuk itu saya mengadakan pelatihan mengenai pemanfaatan teknologi digital marketing untuk usaha memasarkan bakpao ijo dengan digital marketing seperti Instagram dan Facebook yang bisa dijangkau masyarakat luas dari berbagai kalangan serta agar bisa menambah pendapatan dan permintaan pasar UMKM bakpao ijo.

\section{Gambaran Kegiatan Pengabdian}

Kegiatan pengabdian ini terdiri dari tiga tahapan,yakni assessment, kegiatan inti pelatihan, dan kegiatan evaluasi pasca kegiatan. Pada bab ini akan dideskripsikan kegiatan pelatihan mengenai penerapan digital marketing sebagai strategi marketing pada UMKM bakpao ijo lumer milik bapak Mukhlisin 
didesa Milangasri Kecamatan Panekan.

Tahap pertama dalam kegiatan pengabdian adalah Assesment lapangan dilakukan pada hari Rabu tanggal 07 Juli 2021, dari hasil assessment diperoleh gambaran informasi mengenai peserta pelatihan yaitu Bapak Mukhlisin selaku owner atau pemilik UMKM bakpao ijo di KPR Taman Asri tepatnya di desa Milangasri, lokasi pelaksanaan kegiatan yaitu di KPR Taman Asri Desa Milangasri Kecamatan Panekan Kabupaten Magetan, strategi dan uraian kegiatan yang akan dilaksanakan pada kegiatan pelatihan yaitu yang pertama adalah sosialisasi mengenai kegiatan observasi yang akan dilakukan peneliti lalu dilanjutkan dengan pelatihan mengenai pembuatan digital marketing dan penerapan digital marketing sebagai strategi marketing pada UMKM bakpao ijo lumer. Dan selanjutnya dilakukan kegiatan sosialisasi kepada penjual bakpao ijo lumer baik secara langsung maupun melalui media sosial WhatsApp dikarenakan pandemic covid ini jadi pertemuan antara peniliti dengan penjual bakpao juga berkurang dan tidak bisa seintensif pada saat belum ada pandemic covid-19. Sosialisasi yang disampaikan peneliti tersebut berisi hal-hal yang berkaitan dengan kegiatan observasi yaitu mengenai marketing pemasaran atau pejualan bakpao ijo dengan memanfaatkan teknologi yaitu penggunaan digital marketing sebagai strategi marketing untuk penjualan bakpao ijo dalam UMKM bakpao ijo milik Bapak Mukhlisin dan menjelaskan tujuan dan maksud peneliti melakukan observasi yaitu untuk membantu usaha atau UMKM Bakpao ijo milik bapak Mukhlisin dengan memanfaatkan teknologi yang ada yaitu digital marketing, dikarenakan turunnya omset pnjualan bakpao ijo akibat pandemi covid-19 dan diterapkannya PPKM membuat bakpao ijo milik bapak Mukhlisin berkurang penjualnnya, serta melakukan koordinasi dengan penjual bakpao ijo guna untuk kelangsungan observasi agar dapat berjalan dengan baik, lancar, dan sukses.

Kegiatan inti Pelatihan dilaksanakan selama 2 hari yaitu pada hari sabtu dan minggu pada tanggal 2425 Juli 2021 di Rumah bapak Mukhlisin dengan narasumber peniliti sendiri. Acara pelatihan dimulai pada hari Sabtu tanggal 24 Juli 2021, acara pelatihan berlangsung kurang lebih selama 45 menit yang berisi pembukaan berupa sosialisasi mengenai digital marketing apa itu digital dan fungsi dari digital marketing, digital marketing adalah kegiatan pemasaran dengan menggunankan teknologi internet seperti Instagram dan Facebook dengan membuat iklan produk untuk memasarkan produk yang akan dijual sedangkan fungsi dari digital marketing adalah untuk memudahkan penjual dalam memasarkan produknya agar produk miliknya dapat dikenal oleh masyarakat luas dan dengan begitu produk miliknya bisa meningkat penjualannya salah satunya adalah dengan Facebook marketing dengan menggunakan facebook marketing hubungan atau komunikasi antara penjual dengan pembeli dapat terjalin dengan baik dan produk yang diiklankan 
penjual juga dapat dilihat atau dilirik oleh pembeli, dan acara selanjutnya dilanjutkn dengan acara pengarahan membuat digital marketing yang berupa Inserta cara penerapan digital marketing sebagai strategi marketing UMKM bakpao ijo lumer. Acara pada hari pertama adalah memberikan sosialisasi mengenai digital marketing apa itu digital marketing, apa manfaatnya dan seperti apa saja digital marketing, dan bagaimana cara kerja digital marketing untuk mengembangkan penjualan bakpao ijo lumer. Sosialisasi mengenai digital marketing selesai maka dilanjutkan dengan pemberian arahan bagaiamana membuat digital marketing. Peniliti member arahan pembuatan digital marketing dengan memanfaatkan media sosial yaitu Instagram dan juga Facebook, setelah selesai memberikan arahan mengenai pembuatan media sosial peneliti lalu memberikan arahan mengenai cara mengingklankan produk dan bagaimana cara mendesain produk agar terlihat menarik dan dapat dilik pembeli untuk meningkatkan penjualan bakpao ijo. Acara pada hari pertama berlangsung mulai pukul 10.00 sampai pukul 10.50 .

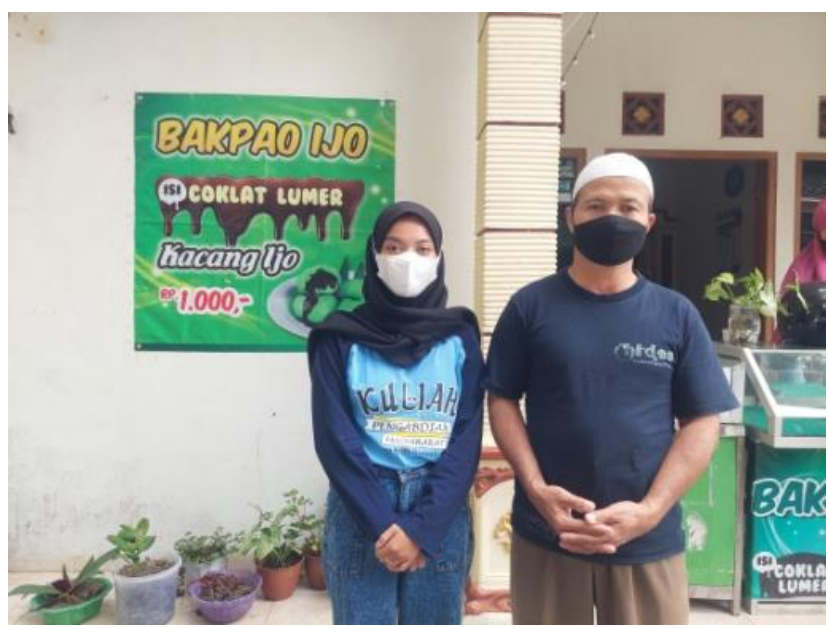

Gambar 1. Pembukaan Sosialisasi

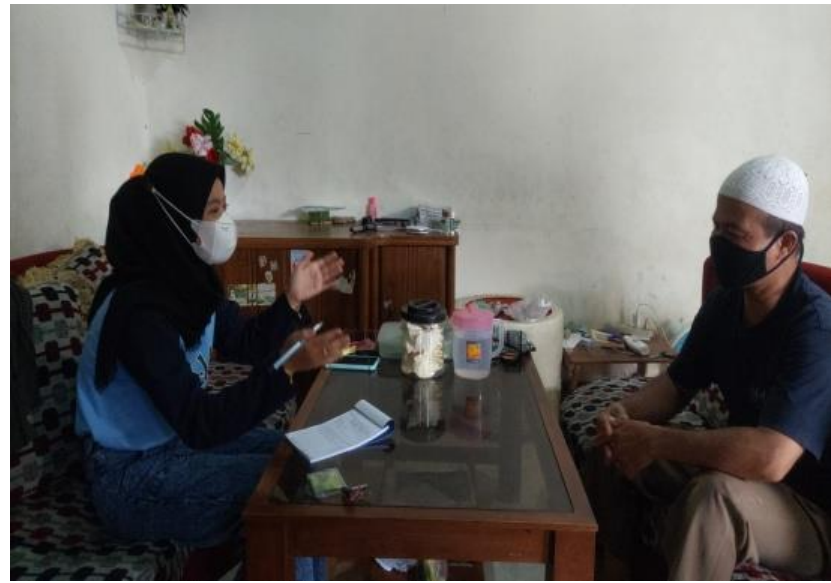

Gambar 2. Kegiatan Sosialisasi 
Lalu acara pada hari kedua dimulai pukul 10.20 dan selesai pukul 11.00, acara pada hari kedua yaitu pada hari Minggu tanggal 25 Juni 2021 dengan acara melanjutkan pelatihan mengenai penerapan digital marketing yaitu perkembangan dari digital marketing berupa media sosial yang telah dibuat dan cara mengiklankan bakpao ijo di media sosial. Pada hari kedua ini bapak Mukhlisin mencoba mengiklankan prodeuk miliknya dengan memosting beberapa foto di media sosial miliknya yaitu Instagram dan Facebook dengan menyertakan beberapa kalimat sebagai caption dalam postingan bapak Mukhlisin, bapak Mukhlisin mengiklankan produk bengan sebaik mungkin untuk menarik minat pembeli. Beliau menunggu beberapa jam sambil menggu pembeli melihat atau mengkomen postingan iklan produk bakapao ijo miliknya, sambil membuat bakpao ijo yang akan disetorkan atau dikirimkan kepada pedagang yang sudah menjadi pelanggannya sejak lama bakpao ijo tersebut akan dikirim kan kedaerah Ngawi tepatnya di Temboro, menurut pembeli bakpao tersebut bakpao yang dibeli tersebut akan dijual kembali kepada para santri disekitar pondok Temboro dengan harga beli dari Bapk Mukhlisin seharga Rp. 800,00 dan dijual kembali oleh pedagang dengan harga Rp. 1000,00 per-pcsnya.

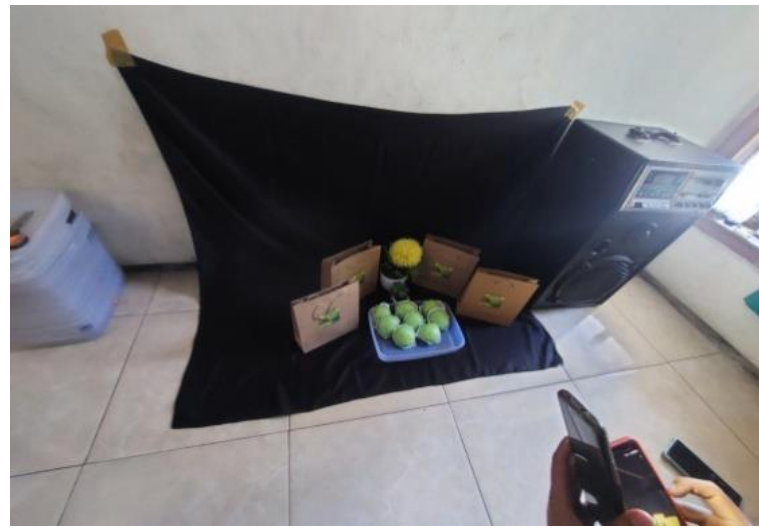

(a)

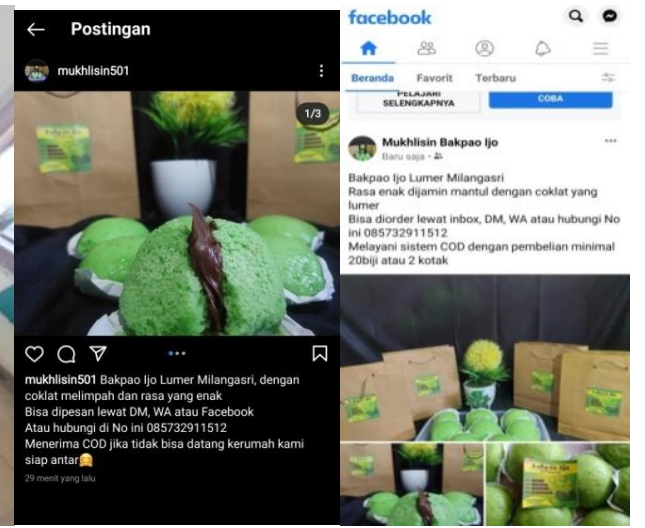

(b) (c)

Gambar 3. (a) Pengambilan gambar iklan produk (b) Pembuatan iklan produk di media Instragram (c) Pembuatan iklan poduk di media Facebook

Evaluasi pasca kegiatan dilakukan untuk mengetahui sejauhmana keberhasilan dari perkembangan pengiklanan bakpao ijo melalui media sosial, target permintaan bertambah atau masih sama saja, tercapainya tingkat penjualan dengan target yang sudah ditentukan, kemampuan penjual bakpao ijo dalam memanfaatkan digital marketing berupa media sosial untuk berjualan, dan kepuasaan penjual bakpao ijo terhadap digital marketing yang sudah dibuat.

\section{Hasil kegiatan}

Pelaksanaan pengabdian dimulai sejak diterimanya usulan pengabdian kepada masyarakat terutama salah satu masyarakat penjual bakpao ijo lumer. Pemahaman tentang penjualan yang baik dan pemanfaatan teknologi yang yang 
baik juga perlu juga dikembangkan dan diperluas. Penjual bakpao ijo merupakan salah satu asset masyarakat yang harus terus dikembangkan dan dipertahankan keberadaannya. Menurunya omset penjualan akibat pandemic covid-19 membuat pendapatan penjual bakpao ijo menurun drastic serta ketersediaan tempat berjualan yang kurang memadai membuat bakapao ijo milik bapak Mukhlisin jarang dikenal dan diketahui banyak orang selain itu juga banyaknya penjual bakpao ijo dari luar desa atau daridaerah lain membuat persaingan antara penjual bakpao ijo semakin ketat dan para penjual mulai mencari strategi penjualan yang dapat menarik minat konsumen.

Ada beberapa hal yang membuat pejualan bakpao ijo dapat meningkat saah satunya yaitu dengan pmanfaatan teknologi yang ada seperti digitl marketing,banyaknya masyarakat yang menggunkan teknologi seperti media sosial membuat penjual bakpao harus lebih kreatif dalam menjual produknya, jika penjual bakpao mulai menggunkan digital marketing dalam pemasaran produk bakpaonya maka penjual bakpao harus memiliki idea tau sesuatu yang dapat menarik minat pembeli seperti dengan cara membuat iklan produk yang menarik dan disukai banyak orang sehingga ketika menonton atau melihat iklan produk pembeli berminat untuk mencoba atauingin merasakan nikmatnya bakpao ijo lumer milik bapak Mukhlisin.

Penjual bakpao ijo lumer belum meiliki lapak atau tempat berdagang yangmenentu sehingga sebelum ada pandemic penjual bakapao menjual daganganny dengan cara berkeliling menaiki sepeda motor sambil menjajakan bakpao ijo buatannya dan berharap laku dan habis setiap hari, namun saat pandemic seperti ini dan adanya kebijakan PPKM membuat penjual bakpao menjadi kesulitan dalam menjual dagangannya dan mau tidak mau penjual bakpao harus memutar otak agar bakpao buatannya bisa laku dan bisa menaikan omset penjualan lebih tinggi lagi. Menurunya omset penjualan tidak hanya membuat penjual bakpao ijo kesulitan dalam mencari nafkah dan juga dalam memenuhi kebutuhan hidup.

Melihat kondisi seperti ini membuat bapak Mukhlisin sebagai penjual bakpao ijo berusaha keras dan mencari cara agar bakpao ijo buatannya tetap laku meskipun dilanda pandemic covid-19 dan penerapan PPKM yang terusberlangsung dan diperpanjang. Kondisi ini juga yang menjadi pertimbangan peneliti untuk mencari cara yang tepar dalam meningkatkan penjualan dan menaikan omset bakpao ijo milik bapak Mukhlisin yaitu dengan penerapan digital markting sebagai strategi marketing untuk UMKM bakpao ijo lumer milik bapak mukhlisin didesa Milangasri.

Hasil pelaksanaan kegiatan pengabdian selanjutnya secara garis besar dapat dilihat dari penilaian beberapa komponen berikut ini, yaitu:

a) Keberhasilan pengiklanan.

Pengiklanan dilakukan di media sosial berupa Instagram, Facebook, dan juga WhatsApp dari ketiga media sosial tersebut 
ada beberapa orang yang bertanya melalui kolom komentar mengenai alamat pembuatan dan jika ingin memesan dan mengambil pesanan apakah bisa dengan menggunakan sistem cod, apakah bisa disorder melalui grabfood atau aplikasi lainnya, dengan demikian bisa dikatakan bahwa pengiklanan yang dilakukan dapat berjalan dengan baik dan mendapat respon baik dari beberapa orang yang kemungkinan berminat membeli bakpao ijo lumer.

b) Target Permintaan.

Target permintaan dari keberhasilan pengiklanan yang dilakukan permintaan bakpao ijo mulai meningkat, ada beberapa orang yang sudah mulai memesan bakpao ijo lumer melalui WhatsApp dan Instagram milik bapak Mukhlisin, target permintaan juga mulai bertambah yang dari awal hanya memesan 1 kotak bakpao ijo kini mulai ada yang memesan 2 kotak ada juga yang 3 kotak bakpao, dengan demikian target permintaan mulai bertambah dan penjualan bakao ijo juga mulai meningkat, dengan demikian permintaan panjualan dan pemesanan pembuatan bakpao ijo bisa terus bertambah dan jangkaun pembeli bakpao ijo juga semakin luas dengan adanya media sosial untuk mengiklankan bakpao ijo yang dibuat semenarik mungkin untuk mearik minat pembeli. c) Kemampuan pemanfaatan digital marketing.

Kemampuan pemanfaatan digital marketing oleh bapak Mukhlisin selaku pembuat dan penjual bakpao ijo terus meningkat seiring dengan pembiasaan diri dalam menggunkan teknologi yang ada, akan tetapi terkadang bapak Mukhlsin sedikit bingung dalam mengiklankan bakpao ijo namun dengan semangat dan tekad bapak Mukhlisin beliau berusaha keras agar bisa memahami teknologi dengan baik dan benar sehingga penjualan bakpao ijo miliknya dapat terus berkembang, beliau memang orang hebat dan tidak mudah putus asa, semua dilakukan agar bakpaoijo miliknya dapat dikenal masyarakatluas.

d) Kepuasan Penjual terhadap digital marketing yang telah dibuat.

Kepuasaan bapak Mukhlisin dalam penerapan digital marketing melalui media sosial membuat omset penjualan dan permintaan pesanan bakpao ijo sedikit demi sedikit mulai meningkat, beliau mrasa bersyukur dan berterimakasih kepada pneliti karena telah membantu dan membimbing beliau dalam menjalankan UMKM bakpao ijo miliknya sehingga sampai saat ini Alhamdulillah penjualan bakpao ijo mulai meningkat dan bapak Mukhlisin bisa memenuhi kebutuhan hidup keluarganya, beliau merasa sangat puas dengan pelatihan ini karena dapat 
meningkatkan pengetahuan dan menambah wawasan mengenai digital marketing.

Evaluasi terhadap penerapan digital marketing dan pemahaman penjual bakpao ijo terhadap pengiklanan di media sosial yang telah dilakukan dalam menarik minat pembeli dengan memberikan desain produk terhadapbakpao ijo lumer dihrapkan mampu menaikanomset dari penjualan bakpaoijo, dan ternyata benar saja selang beberapa hari dari iklan produk atau makanan bakpao ijo ini yang diposting ada beberapa pembeli yang berminat membeli bakpao ijo. Ada 2 orang yang memesan bakpao ijo lumer melalui akun media sosial Instagram dan dilanjutkan transaksi melalui WhatsApp, 2 orang tersebut memesan 4 kotak bakpao ijo yang masing-masing memesan 2 kotak, pesanan tersebut akan dijual kembali. Bapak Mukhlisin memberikan harga Rp.800,00 kepada pembeli atau pemesan sedangkan pembeli atau pemesan bisa menjual kembali bakpao ijotersebut dengan harga Rp.1000,00 dengan begitu pembeli atau pemesan mendapat keuntungan Rp.200,00 per pcsnya.

Hasil Evaluasi terhadap penerapan digital marketing adalah bapak Mukhlisin berhasil dan mampu menggunakan digital marketing yang berupa media sosial untuk mengiklankan dan menjual produk bakpao ijo miliknya, beliau bisa membuat akun media sosial yaitu Instagram dan Facebook dan dari kedua akun tersebut beliau bisa membuat iklan produk dengan memposting beberapa foto bakpao ijo lumer miliknya dan varian rasa dari bakpao ijo sehigga nanti jika ada pembeli atau orang yang melihat iklan produknya akan tertarik dan berminat untuk membeli. Selain itu digital marketing juga berutujuan untuk memberikan kepuasan, kepercayaan dan hubungan yang baik antara penjual dan pembeli. Maksud dari kepuasaan adalah kepuasan pelanggan terhadap barang atau produk yang dijual, jadi kepuasan pelanggan merupakan keadaan dimana pembeli merasakan manfaat atau kegunaan dari produk yang dibeli dapat memenuhi harapan dan melebihi eskpektasi dari pembeli atau pelanggan (Irawan, 2002:3)

Evaluasi pemahaman terhadap pengiklanan dimedia sosial adalah bapak Mukhlisin dengan mudah memposting foto atau gambar bakpao ijo miliknya untuk diiklankan, dan bapak mukhlisin membuat capton atau status dalam unggahan pengiklanan yang akan diposting dengan semenarik mungkin untuk dapat menarik minat pembeli, jadi pemahaman bapak Mukhlisin terhadap pengiklanan di media sosial adalah sangat baik dan beliau juga mudah dalam menerima saran atau masukan dari peneliti mengenai pengiklanan yang baik dan yang menarik. Bapak Muklisin awalnya tidak terfikirkan mengenai penggunaan digital marektin untuk menjual produknya namun berkat sosialisasi ari peniliti sekarang beliau sudah bisa berpikir kritis, apalagi situasi pandemi seperti ini penjual harus mampu mencari cara atau strategi bagaimana agar bisa tetap terus berjualan dan bisa menaikan omset penjualan. Dengan digital marketing ini maka bakpao ijo milik bapak Mukhlisin bisa dikenal dan 
dicari di media sosial Instagram dan juga Facebook dan bisa memudahkan pembeli yang berminat atau ingin membeli bakpao.

Menurut bapak Mukhlisin dengan adanya pelatihan penerapan digital marketing ini membuat beliau bisa belajar banyak sekali manfaat dari teknologi selain untuk hiburan dan permainan ternyata juga dapat bermanfaat pagi penjualannya yaitu untuk memasarkan roduknya dengan penggunaan digital marketing "Selama ini saya hanyau taunya kalo teknologi yang ada itu hanya untuk hiburan, biasanya saya hanya menggunakan $\mathrm{Hp}$ saya untuk menonton Youtube dan juga digunakan anak saya untuk bermain game, tapi ternyata banyak sekali manfaatnya salah satunya ya ini berjualan dengan menggunakan digital marketing dan membuat akun media sosial untuk memasang iklan bakpao bauatan saya".

Berdasarkan hasil observasi yang peneliti lakukan mengenai Pelatihan Penerapan Digital Marketing Sebagai Strategi Marketing Pada UMKM Bakpao Ijo Lumer Bapak Mukhlisin Berjalan dengan lancar dan sukses, dan bapak Mukhlisin mendapat banyak sekali wawasan dan pengetahuan mengenai teknologi terutama digital marketing untuk memasarkan produknya dengan menggunakan media sosial yaitu Instagram dan juga Facebook, beliau juga bisa membuat iklan produk agar terlihat menarik dan dapat menarik minat konsumen atau pembeli sehingga konsumen atau pembeli yang melihat iklan produk dari bapak Mukhlisin mau membeli bakpao ijo lumer buatan bapak Mukhlisin.

\section{PENUTUP}

Berdasarkan uraian dalam pemmbahasan diatas, maka dapat diperoleh kesimpulan, antara lain yaitu: Kegiatan observasi yang dilakukan berjalan dengan baik, lancar dan sukses serta dari seluruh kegiatan observasi yang dilakukan mulai dari menggali potensi, menemukan potensi, sosialisasi kepada salah satu masyarakat dengan potensi yang ada untuk bisa dkembangkan sampai dengan hasil observasi yang dilakukan mendapat banyak sekali pengalaman, wawasan dan ilmu yang bermanfaat baik bagi peneliti maupun masyarakat. Observasi yang dilakukan dengan judul pelatihan penerapan digital marketing sebagai strateg marketing pada umkm bakpao ijo lumer milik bapak mukhlisin berjalan dengan lancar, dan bapak Mukhlisun sendiri mampu dan bisa beradaptasi dengan kegiatan pelatihan yang dilakukan, beliau bisa mnggunakan teknlogi dengan sebaik mungkin salah satunya adalah digital marketing, yang awalnya hanyau mengetahui manfaat teknologi untuk hiburan dan bernain game sekarang sudah bisa memanfaatkan teknologi untuk mengembangkan bisnis miliknya yaitu berjualan bakpao ijo lumer. Yang akibat pandemic covid-19 penjualan bakpao ijo lumer miliknya menurun dan sepi pembeli dikarnakan adanya kebijakan yang awalnya diterapkan kebijakan Lockdown dan sekarang semakin diperketat dengan kebijakan PPKM yang 
membuat beliau tidak bisa berjualan keliling lagi sehingga pendapatannya menurun, namun setelah kegiatan pelatihan ini dilakukan perlahan penjualan bakpao ijo lumer miliknya perlahan mulai membaik kembali, beliau mulai menerima pesanan bakpao ijo dengan jumlah yang perlahan banyak. Saran kami Dengan menggunakan digital marketing yaitu dengan membuat media sosial berupa Instagram dan Facebook beliau mengiklankan produk bakpao ijo miliknya dengan mebuat iklan semenarik mungkin dan alhasil bisa membuat pembeli memesan bakpaoijolumer buatannya. Jadi pelaksanaan pelatihan penerapan digital marketing secara keseluruhan dikatakan berhasil hal ini dapat dilihat dari pemahaman bapak Mukhlisin terhadap sosialisasi peatihan dan penerapan digital marketing yang dilakukan dengan hasil yang dihasilkan dari keseluruhan kegiatan yang dilakukan.

\section{DAFTAR PUSTAKA}

Amri, A. (2020). Dampak Covid-19 Terhadap UMKM Di Indonesia. Jurnal Brand, 2(1), 123-130

Ahmadi, dan Dkk. (2021). Pedoman KPM-DDR 2021 Institut Agama Islam Negeri Ponorogo. Ponorogo: LPPM IAIN Ponorogo.

Durianto, D., Sugiarto dan Budiman, L. J. (2004). STRATEGI Memimpin Pasar. Jakarta: PT Gramedia Pustaka Utama.

Hadiwinata, K., Mundzir, H., Muslim, S. (2020). Analisis Peran Media Sosial Instagram Sebagai Media
Pemasaran dan Branding Bisnis di Era Pandemi Covid-19. Seminar Nasional Administrasi Bisnis dan Manajemen(SENABISMA), issn 2442-5486, 6, B62-B68.

Ihza, K.N. (2020). Dampak Covid-19 terhadap UMKM (Studi Kasus UMKM Ikhwa Comp Desa Watesprojo, Kemlagi, Mojokerto). Jurnal Inovasi Penelitian, 1(7), 1325-1330.

Irfansyah, H., Yusida, E. (2020). Strategi Pemasaran Dengan Menggunakan Media Instagram Pada FolkeCoffe Selama Pandemik Covid-19. Proseding Hapemas Universitas Negeri Malang, 1(1), 618-626.

Irawan, H. (2002). 10 Prinsip Kepuasan Pelanggan. Jakarta: PT Elex Media Komputindo

Kotler dan Philip. 2004. Dasar-Dasar Pemasaran. Penerrbit Erlangga. Jakarta.

Pakpan, A. K. (2002). COVID-19 dan Implikasi Bagi Usaha Mikro Kecil Menengah.

Salahudin, Nadhir dan Dkk. (2015). Panduan KKN ABCD UIN Sunan Ampel Surabaya. Surabaya: LP2M UIN Sunan Ampl Surabaya.

Soetjipto, N. (2002). Ketahanan UMKM Jawa Timur Melintasi Pandemi COVID-19. Yogyakarta: K-media.

Soetomo, (2009). Pembangunan Masyaraktat. Yogyakarta: Pustaka Pelajar.

Wawancara dengan Bapak Mukhlisin Penjual Bakpao Ijo Lumer. 25 Juni 2021. 